\title{
IN VITRO INHIBITORY EFFECTS OF THE ETHANOL EXTRACT OF Tetrapleura tetraptera (Schum and Thonn.) Taub. AGAINST MULTIDRUG RESISTANT Staphylococcus aureus
}

\author{
Olufunmiso Olusola Olajuyigbe ${ }^{1,2 *}$, Anthony J. Afolayan ${ }^{2}$ \\ ${ }^{1}$ Department of Microbiology, Babcock University, PMB 4005, Ilisan Remo, \\ Ogun State, Nigeria \\ ${ }^{2}$ Medicinal Plants and Economic Development Research Centre, University of Fort Hare, \\ Alice, 5700, South Africa \\ *Corresponding author; E-mail: funmijuyigbe12@yahoo.com
}

(Received October 2, 2017; Accepted January 19, 2018)

\begin{abstract}
In this study, the antibacterial effect of ethanol extract of Tetrapleura tetraptera was investigated in vitro against methicillin-resistant Staphylococcus aureus by agar diffusion and macrobroth dilution methods. At the lowest concentration of $20 \mathrm{mg} / \mathrm{ml}$ of the ethanol extract, $100 \mu 1$ produced inhibition zones that ranged between 06 and $15 \pm$ $1.0 \mathrm{~mm}$ while the inhibition zones ranged between $16 \pm 1.0 \mathrm{~mm}$ and $22 \pm 1.0 \mathrm{~mm}$ when the isolates were tested with $100 \mu \mathrm{l}$ of the highest concentration $(100 \mathrm{mg} / \mathrm{ml})$ of ethanol extract. The minimum inhibitory concentrations (MICs) of the ethanol extract were between $0.019 \mathrm{mg} / \mathrm{ml}$ and $5.0 \mathrm{mg} / \mathrm{ml}$ while its minimum bactericidal concentrations (MBCs) ranged between 0.078 and $10.0 \mathrm{mg} / \mathrm{ml}$. Ten strains had their MICs less than 1.0 $\mathrm{mg} / \mathrm{ml}$ while the remaining $S$. aureus strains had their MICs at concentrations ranging between $1.25 \mathrm{mg} / \mathrm{ml}$ and $5.0 \mathrm{mg} / \mathrm{ml}$. The degree of antibacterial activity exhibited by the extract of $T$. tetraptera demonstrated that its herbal medicine could be as effective as modern medicine in treating diseases associated with the test pathogenic organism and justifying its traditional use in the treatment of bacterial infections.
\end{abstract}

Keywords: Antistaphylococcal activities, inhibitory concentrations, ethanol extract, $T$. tetraptera.

\section{INTRODUCTION}

Although its isolation from urine samples is repeatedly secondary to staphylococcal bacteremia arising in cases like endocarditis in certain patients, Staphylococcus aureus is an important pathogen associated with inpatients and community infections (MILLAR et al., 2007). It colonises about $30 \%$ of human population (WERTHEIM et al., 2005). It is frequently isolated from abscesses, whitlows, paronychia and infected eczema (ROTTER, 1999) and has been implicated in ascending urinary tract colonization and infection (MUDER et al., 2006). Methicillin-resistant $S$. aureus (MRSA) is the most important healthcare associated infectious agent as a result of its presence in up to $20 \%$ of inpatients and $16 \%$ of healthcare workers and its ability to survive on surfaces for over 12 days (NIJSSEN et al., 2005; HUANG et al., 2006). 
A "search and destroy" method, a difficult but intuitively sensible task to perform (PASTILA et al., 2004; FARIA et al., 2005) when used together in a concerted manner (VoSS, 2004), is a multipronged approach to keeping MRSA infection prevalence low.

To avoid establishment of infection, antibiotic prophylaxis has become the standard of care (DAROUICHE, 2003; BLOCK and STUBBS, 2005). However, the undesirable side effects of certain antibiotics and the emergence of previously uncommon infections (MARCHESE et al., 2001) have forced scientists into having considerable interest in the use of plant materials as an alternative method to control pathogenic microorganisms (AQIL et al., 2005; CHOI et al., 2010). Thus, about $20 \%$ of the plants found growing in the world have, therefore, been investigated for their pharmacological importance (SUFFREDINI et al., 2004). Many studies showed that higher plants represent a potential source of potent antimicrobial and new bioactive compounds (NJUME et al., 2011; OLAJUYIGBE and AFOLAYAN, 2012) and accredited the value of plants for medicinal purposes (ARIAS et al., 2004; AYOKA et al., 2008; PRUSTI et al., 2008). In ethnomedicine, the medicinal plants are used in treating and preventing specific ailments and diseases (ANSELEM, 2004). While the advent of bacterial resistance and the occurrence of undesirable side effects of some antibiotics (SOBERON et al., 2007) has become a global challenge, there is an increase in the demand for medicinal plants constituting a reservoir of new antimicrobial substances yet to be discovered (MAKANJUOLA et al., 2010).

Tetrapleura tetraptera is a perennial plant which grows in the lowland forest along the Western Coast of Africa. It is a species of flowering plants in the pea family (Fabaceae) and a deciduous forest plant belonging to the Mimosoideae Sub-family (AKIN-IDOWU et al., 2011). Ethnomedically, the leaves, fruit, bark and pod are used for medicinal purposes (STEENTOFT, 1988). The fruits are used in the management of jaundice, flatulence, fever (BOUQUET, 1971), convulsion, leprosy, inflammation and rheumatism (OJEWOLE and ADESINA, 1983) as well acting as antiparasitic, antidiabetic and anti-inflammatory agents (OJEWOLE and ADEWUNMI, 2004; OJEWOLE, 2005) The dried fruits have a pleasant aroma (AladESANMI, 2007) and are popularly used as a seasoning spice in Southern and Eastern Nigeria (OKWU, 2003). Pharmacologically, T. tetraptera has anti-inflammatory (ONDA et al., 2017) and antioxidant activities (BADU, 2012) and possess chemical compounds such as triterpenoid glycoside, flavonoids and phenols (MAILlARD et al., 1992). While ADERIBIGBE et al. (2007) indicated that the bark has neuropharmacological activity, LEKANA-DOUKI et al. (2011) reported that it has antiplasmodial activity. The leaves are used for the treatment of epilepsy (NWAIWU and AKAH, 1986). The aqueous fruit extract possesses hypoglycaemic property (OJEWOLE and ADEWUNMI, 2004). Although there are informations on the ethnopharmacological and nutritional value of T. tetraptera (IRONDI et al., 2013; AKINTOLA et al., 2015; ADESINA et al., 2016), there is a dearth of scientific information on the therapeutic significance of this plant. This study, therefore, investigated the inhibitory effects of the ethanol stem bark extract of $T$. tetraptera against multidrug methicillin-resistant $S$. aureus from urine samples to justify its ethnomedicinal importance.

\section{MATERIALS AND METHODS}

\section{Collection of plant material}

The bark of T. tetraptera was collected in May 2016, from the plant growing within a rural settlement in Ogun State, Nigeria. The plant was authenticated ethnobotanically by Prof. O. Adedayo, Kwara State University, Kwara State, Nigeria while voucher specimen was being prepared. 


\section{Extract preparation}

The bark sample was air-dried at room temperature, pulverized with a milling machine and extracted as described by OlaJUYIGBE and AfOLAYAN (2012). Briefly, $200 \mathrm{~g}$ of the pulverized sample was extracted with $1000 \mathrm{ml}$ of ethanol for $72 \mathrm{~h}$ with shaking (Stuart Scientific Orbital Shaker, Staffordshire, UK). The extract was filtered through Whatman No. 1 filter paper and concentrated under reduced pressure at $40^{\circ} \mathrm{C}$ using a rotary evaporator (Laborota 4000-efficient, Heldolph, city, Germany). The extraction was done for two more consecutive times. The crude extract collected was dried at room temperature to a constant weight. The extract was later dissolved in the extracting solvent to the required concentrations for bioassay analysis. The reconstituted extract solution was filtered through $0.45 \mu \mathrm{m}$ membrane filter and tested for sterility after membrane filtration by introducing $2 \mathrm{ml}$ of the extract in $10 \mathrm{ml}$ of sterile nutrient broth before being incubated at $37{ }^{\circ} \mathrm{C}$ for $24 \mathrm{~h}$. A sterile extract was indicated by the absence of turbidity in the broth after the incubation period.

\section{Test organisms and inocula preparation}

In this study, eighteen clinical strains of $S$. aureus obtained from urine samples and two typed strains S. aureus (ATCC 6538 and NCT 6571) used as control were tested. Bacteriologically, each of the clinical strains of $S$. aureus was streaked on mannitol salt agar (MSA) and nutrient agar which were incubated overnight at $37{ }^{\circ} \mathrm{C}$ for $24-48 \mathrm{~h}$ (FoRBES and SAHM, 2007). The bacterial colonies were subjected to Gram staining, microscopic appearance, colony morphology and biochemical tests such as tube coagulase test according to standard protocols (HolT et al., 1994; CHEESBROUGH, 2002, 2009). The inocula of the test S. aureus strains were prepared using the colony suspension method (EUCAST, 2000). Colonies picked from $24 \mathrm{~h}$ old cultures grown on nutrient agar were used to make suspensions of the test organisms in saline solution to give an optical density of approximately 0.1 at 600 $\mathrm{nm}$. The suspensions were then diluted 1:100 by inoculating $9.9 \mathrm{ml}$ of sterile nutrient broth with $100 \mu \mathrm{l}$ of the bacterial suspension and thoroughly agitated before being used.

\section{Determination of methicillin resistant Staphylococcus aureus}

The susceptibility of $S$. aureus isolated from urine samples to different antibiotics including cefoxitin $(30 \mu \mathrm{g})$ (Table 1) was determined by modified Kirby-Bauer disc diffusion method following CLSI guidelines (CLSI, 2013). The strains of S. aureus which were found to be resistant to cefoxitin were screened as MRSA. The methicillin susceptibility assay was determined by macrobroth dilution using oxacillin at concentrations ranging between 0.0156 and $128 \mu \mathrm{g} / \mathrm{ml}$.

\section{Antibacterial assay by agar diffusion method}

For the initial determination of the antibacterial activity of the ethanol extract of $T$. tetraptera, the susceptibility screening of the test bacteria to the extract was determined by using the modified Kirby-Bauer diffusion technique (EUCAST, 2000) involving swabbing Mueller-Hinton agar (MHA) (Lab M Ltd, Quest Park, Lancashire, UK) plates with the resultant saline suspension of each adjusted strain of $S$. aureus. Wells were then bored into the agar medium with a heat sterilized $6 \mathrm{~mm}$ cork borer. The wells were later filled with $100 \mu \mathrm{l}$ of $20 \mathrm{mg} / \mathrm{ml}, 40 \mathrm{mg} / \mathrm{ml}, 60 \mathrm{mg} / \mathrm{ml}, 80 \mathrm{mg} / \mathrm{ml}$, and $100 \mathrm{mg} / \mathrm{ml}$ concentrations of the extract taking care not to allow spillage of the solutions onto the agar surface. An antibiotic disk 
containing $200 \mu \mathrm{g}$ of nitrofurantoin was included as a control. The culture plates were allowed to stand on the laboratory bench for $1 \mathrm{~h}$ for proper diffusion of the dispensed extract solutions before being incubated at $37{ }^{\circ} \mathrm{C}$ for $24 \mathrm{~h}$. Wells in blank Mueller Hinton agar containing $5 \%$ ethanol representing the final concentration of the ethanol in the test plates without the extract served as negative control. The determinations were done in duplicates. After $24 \mathrm{~h}$ of incubation, the plates were examined for the presence of inhibition zones. While the diameters of the inhibition zones produced by each concentration of the extract was measured in millimetres (WIKLER, 2007), the break point with an inhibition zone of diameter $\geq$ 11 was chosen for bacterial susceptibility to the plant extracts (NYENJE and NDIP, 2011).

\section{Macrobroth dilution for determining minimum inhibitory concentration (MIC)}

Minimum inhibitory concentration (MIC) defined as the lowest concentration of the extract which resulted in maintenance or reduction of inoculums' viability was determined by macrobroth tube dilution technique (KHAN et al., 2007) for the S. aureus strains. Different concentrations ranging from $0.098 \mathrm{mg} / \mathrm{ml}$ to $20 \mathrm{mg} / \mathrm{ml}$ of the crude extract prepared by serial dilutions in double strength Mueller Hinton broth medium. A set of tubes was then inoculated with $100 \mu \mathrm{l}$ of the appropriate strains. Two blank Mueller Hinton broth tubes, with and without bacterial inoculation, were used as the growth and sterility controls. The tubes were incubated at $37^{\circ} \mathrm{C}$ for $24 \mathrm{~h}$. After the incubation period, the tubes were observed for the MICs by checking the concentration of the first tube in the series of tubes that showed no visible trace of growth. The lowest concentration in the series with no visible growth after the incubation period was taken as the MICs.

\section{Determination of minimum bactericidal concentrations (MBCs)aliquots}

Since the clinical occurrences of tolerance usually necessitate bactericidal testing, the MBC was determined by sampling all the macroscopically clear tubes and the first turbid tube in the MIC series. Before being sampled, the tubes were gently mixed by flushing them with a sterile pipette, and a $100 \mu \mathrm{l}$ aliquot was removed. Each aliquot was placed on antibiotic-free nutrient agar plate in a single streak down the centre of the plate in accordance with the method of SHANHOLTZER et al. (1984). The samples were allowed to be absorbed into the agar until the plate surface appeared dry (after $30 \mathrm{~min}$ ). The aliquot was then spread over the plate by making a lawn of the bacterial culture with sterile cotton swab. In many studies on microbial susceptibility, this subculturing method has been found satisfactory in eliminating the problem of antimicrobial agent carryover from the $100 \mu \mathrm{l}$ subcultured volume (MoODY et al., 1987; FASCHING et al., 1990). The growth and sterility controls were sampled in the same manner. The MBC determining plates were incubated for $24 \mathrm{~h}$ at $37^{\circ} \mathrm{C}$. After the incubation periods, the lowest concentrations of the extract that did not produce any bacterial growth on the solid medium were regarded as the MBC values for this crude extract. This observation was matched with the MIC test tube that did not show evidence of growth after $48 \mathrm{~h}$ of incubation.

\section{RESULTS AND DISCUSSION}

In this study, strains of $S$. aureus with inhibition zone $\leq 21$ to cefoxitin disc (30 $\mu \mathrm{g})$ and having oxacillin MIC $\geq 4 \mu \mathrm{g} / \mathrm{ml}$ were regarded as methicillin resistant strains as presented in Table 1. The susceptibility of different strains of $S$. aureus using ethanol extract of $T$. tetraptera was determined by agar diffusion assay while the degree of the antibacterial 
activity of the extract was determined by macrobroth dilution method. The results were presented in Table 2. The susceptibility of the isolates was concentration dependent. $100 \mu 1$ of the different concentrations of the extract produced varied degree of inhibition zones. The diameters of inhibition zones decrease with decreases in the concentrations of ethanol extract. At the lowest concentration of $20 \mathrm{mg} / \mathrm{ml}$ of the ethanol extract, $100 \mu \mathrm{l}$ produced inhibition zones that ranged between 6 and $15 \pm 1.0 \mathrm{~mm}$ while the inhibition zones ranged between $16 \pm$ $1.0 \mathrm{~mm}$ and $22 \pm 1.0 \mathrm{~mm}$ when the isolates were tested with $100 \mu \mathrm{l}$ of the highest concentration of ethanol extract. On the other hand, the nitrofurantoin antibiotic disk inhibited thirteen of the isolates with inhibition zones ranging between 20 to $37 \pm 1.0 \mathrm{~mm}$.

Table 1: Susceptibility of Staphylococcus aureus isolated from urine samples to different antibiotic disks.

\begin{tabular}{|c|c|c|c|c|c|c|c|c|c|}
\hline \multirow[b]{2}{*}{$\begin{array}{c}\text { Test } \\
\text { Staphylococcus } \\
\text { strains }\end{array}$} & \multicolumn{8}{|c|}{$\begin{array}{c}\text { Inhibition zones produced by different antibiotic discs } \\
\text { against strains of } S \text {. aureus }\end{array}$} & \multirow[b]{2}{*}{$\begin{array}{l}\text { Oxacillin } \\
\text { (MIC) } \\
\mu \mathrm{g} / \mathrm{ml}\end{array}$} \\
\hline & $\begin{array}{c}\mathrm{Clx} \\
(5 \mu \mathrm{g})\end{array}$ & $\begin{array}{c}\text { Ery } \\
(5 \mu \mathrm{g})\end{array}$ & $\begin{array}{l}\text { Gen } \\
(10 \\
\mu \mathrm{g})\end{array}$ & $\begin{array}{c}\text { Aug } \\
(30 \\
\mu \mathrm{g})\end{array}$ & $\begin{array}{l}\text { Tet } \\
(10 \\
\mu \mathrm{g})\end{array}$ & $\begin{array}{l}\text { Chl } \\
(10 \\
\mu \mathrm{g})\end{array}$ & $\begin{array}{c}\text { Ofl } \\
(5 \mu \mathrm{g})\end{array}$ & $\begin{array}{l}\text { Cfx } \\
(30 \\
\mu \mathrm{g})\end{array}$ & \\
\hline SA 1 & 0 & 28 & 0 & 0 & 0 & 0 & 0 & 0 & 8 \\
\hline SA 2 & 0 & 30 & 30 & 12 & 0 & 0 & 24 & 14 & 4 \\
\hline SA 3 & 0 & 30 & 32 & 0 & 0 & 11 & 25 & 12 & 4 \\
\hline SA 4 & 18 & 32 & 20 & 32 & 0 & 36 & 28 & 17 & 8 \\
\hline SA 5 & 0 & 32 & 23 & 10 & 0 & 0 & 26 & 17 & 4 \\
\hline SA 6 & 0 & 0 & 34 & 12 & 0 & 12 & 26 & 14 & 8 \\
\hline SA 7 & 0 & 29 & 26 & 11 & 0 & 0 & 27 & 11 & 16 \\
\hline SA 8 & 0 & 18 & 20 & 20 & 19 & 11 & 25 & 14 & 8 \\
\hline SA 9 & 8 & 21 & 24 & 0 & 0 & 16 & 31 & 17 & 16 \\
\hline SA 10 & 0 & 15 & 36 & 15 & 0 & 14 & 15 & 16 & 4 \\
\hline SA 11 & 17 & 28 & 16 & 22 & 15 & 25 & 30 & 20 & 4 \\
\hline SA 12 & 0 & 15 & 36 & 15 & 0 & 14 & 15 & 16 & 8 \\
\hline SA 13 & 30 & 0 & 20 & 30 & 0 & 20 & 0 & 20 & 4 \\
\hline SA 14 & 0 & 28 & 35 & 0 & 0 & 0 & 27 & 15 & 16 \\
\hline SA 15 & 0 & 29 & 26 & 11 & 0 & 0 & 27 & 11 & 8 \\
\hline SA 16 & 0 & 18 & 20 & 20 & 19 & 11 & 25 & 14 & 4 \\
\hline SA 17 & 26 & 38 & 19 & 16 & 0 & 0 & 13 & 18 & 4 \\
\hline SA 18 & 0 & 30 & 32 & 0 & 0 & 11 & 25 & 12 & 8 \\
\hline
\end{tabular}

Key: Clx = Cloxacillin; Ery = Erythromycin; Gen = Gentamicin; Aug = Augmentin; Tet $=$ Tetracycline Chl $=$ Chloromphenicol; Ofl = Ofloxacin $(5 \mu \mathrm{g}) ; \mathrm{Cfx}=$ Cefoxitin .

The degree of the antibacterial activity of T. tetrapleura against the isolated S. aureus as determined by the macrobroth dilution assay is presented in Table 3. The MICs of the ethanol extract were between $0.019 \mathrm{mg} / \mathrm{ml}$ and $5.0 \mathrm{mg} / \mathrm{ml}$ while its MBCs ranged between 0.039 and $10.0 \mathrm{mg} / \mathrm{ml}$. Of the ten isolates that had their MICs at concentrations less than 1.0 $\mathrm{mg} / \mathrm{ml}$, seven had their MICs at concentrations $0.019 \mathrm{mg} / \mathrm{ml}$, one strain had a MIC of 0.039 $\mathrm{mg} / \mathrm{ml}$, two strains had MIC of $0.325 \mathrm{mg} / \mathrm{ml}$ while the remaining $S$. aureus strains had their MICs at concentrations ranging between $1.25 \mathrm{mg} / \mathrm{ml}$ and $5.0 \mathrm{mg} / \mathrm{ml}$.

In this study, the degree of the antibacterial activity of the ethanol stem bark extract of T. tetraptera was very high. The extract was able to effectively inhibit $50 \%$ of the test organisms at concentrations less than $1000 \mu \mathrm{g} / \mathrm{ml}$ while the isolates inhibited at 
concentrations less than $1000 \mu \mathrm{g} / \mathrm{ml}$ had their MICs at concentrations ranging between 0.019 and $0.3125 \mathrm{mg} / \mathrm{ml}$. ElOFF (2008) and KUETE (2010) classified the antimicrobial activity of plant extracts and fractions to be significant if the MIC is $0.1 \mathrm{mg} / \mathrm{ml}$ or lower, moderate if 0.1 $<$ MIC $\leq 0.625 \mathrm{mg} / \mathrm{ml}$ and weak if MIC $>0.625 \mathrm{mg} / \mathrm{ml}$. Based on these criteria, the ethanol extract had significant antibacterial activity against eight strains of $S$. aureus with MICs of $0.019 \mathrm{mg} / \mathrm{ml}$, moderate activity against two strains with MICs of $0.3125 \mathrm{mg} / \mathrm{ml}$ while it was weak against the rest of the strains having MICs ranging from 1.25 and $5 \mathrm{mg} / \mathrm{ml}$. Although previous studies have focused on the antibacterial activities of the fruit extracts of this plant (ACHI, 2006; AWOFISAYO et al., 2010), this study indicated the antibacterial activity of its stem bark extract against human bacterial pathogen.

Table 2: Antistaphylococcal effects of ethanol extract of Tetrapleura tetraptera by agar diffusion assay.

\begin{tabular}{|c|c|c|c|c|c|c|}
\hline \multirow[b]{2}{*}{$\begin{array}{c}\text { Test } \\
\begin{array}{c}\text { Staphylococcus } \\
\text { strains }\end{array} \\
\end{array}$} & \multicolumn{5}{|c|}{$\begin{array}{c}\text { Inhibition zones produced by } 100 \mu \mathrm{l} \text { of different } \\
\text { concentrations of ethanol extract }( \pm 1.0 \mathrm{~mm})\end{array}$} & \multirow{2}{*}{$\begin{array}{c}\text { Nitrofurantoin } \\
\mathbf{3 0}\end{array}$} \\
\hline & 100 & 80 & 60 & 40 & 20 & \\
\hline & \multicolumn{5}{|c|}{ 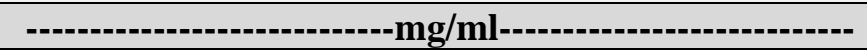 } & $\mu \mathrm{g} / \mathrm{ml}$ \\
\hline SA 1 & $22 \pm 1.0$ & $20 \pm 1.0$ & $18 \pm 1.0$ & $16 \pm 1.0$ & $15 \pm 1.0$ & $20 \pm 1.0$ \\
\hline SA 2 & $20 \pm 1.0$ & $18 \pm 1.0$ & $16 \pm 1.0$ & $15 \pm 1.0$ & $13 \pm 1.0$ & $06 \pm 1.0$ \\
\hline SA 3 & $17 \pm 1.0$ & $16 \pm 1.0$ & $14 \pm 1.0$ & $14 \pm 1.0$ & $06 \pm 1.0$ & $20 \pm 1.0$ \\
\hline SA 4 & $19 \pm 1.0$ & $15 \pm 1.0$ & $16 \pm 1.0$ & $15 \pm 1.0$ & $15 \pm 1.0$ & $06 \pm 1.0$ \\
\hline SA 5 & $20 \pm 1.0$ & $18 \pm 1.0$ & $16 \pm 1.0$ & $15 \pm 1.0$ & $15 \pm 1.0$ & $28 \pm 1.0$ \\
\hline SA 6 & $17 \pm 1.0$ & $15 \pm 1.0$ & $13 \pm 1.0$ & $14 \pm 1.0$ & $13 \pm 1.0$ & $06 \pm 1.0$ \\
\hline SA 7 & $18 \pm 1.0$ & $15 \pm 1.0$ & $14 \pm 1.0$ & $14 \pm 1.0$ & $12 \pm 1.0$ & $06 \pm 1.0$ \\
\hline SA 8 & $16 \pm 1.0$ & $15 \pm 1.0$ & $15 \pm 1.0$ & $14 \pm 1.0$ & $14 \pm 1.0$ & $06 \pm 1.0$ \\
\hline SA 9 & $18 \pm 1.0$ & $16 \pm 1.0$ & $15 \pm 1.0$ & $15 \pm 1.0$ & $14 \pm 1.0$ & $06 \pm 1.0$ \\
\hline SA 10 & $20 \pm 1.0$ & $17 \pm 1.0$ & $14 \pm 1.0$ & $15 \pm 1.0$ & $15 \pm 1.0$ & $33 \pm 1.0$ \\
\hline SA 11 & $17 \pm 1.0$ & $16 \pm 1.0$ & $15 \pm 1.0$ & $15 \pm 1.0$ & $12 \pm 1.0$ & $25 \pm 1.0$ \\
\hline SA 12 & $17 \pm 1.0$ & $16 \pm 1.0$ & $15 \pm 1.0$ & $15 \pm 1.0$ & $15 \pm 1.0$ & $30 \pm 1.0$ \\
\hline SA 13 & $19 \pm 1.0$ & $16 \pm 1.0$ & $14 \pm 1.0$ & $14 \pm 1.0$ & $13 \pm 1.0$ & $26 \pm 1.0$ \\
\hline SA 14 & $19 \pm 1.0$ & $17 \pm 1.0$ & $15 \pm 1.0$ & $12 \pm 1.0$ & $12 \pm 1.0$ & $23 \pm 1.0$ \\
\hline SA 15 & $20 \pm 1.0$ & $17 \pm 1.0$ & $14 \pm 1.0$ & $15 \pm 1.0$ & $14 \pm 1.0$ & $06 \pm 1.0$ \\
\hline SA 16 & $22 \pm 1.0$ & $19 \pm 1.0$ & $17 \pm 1.0$ & $16 \pm 1.0$ & $15 \pm 1.0$ & $35 \pm 1.0$ \\
\hline SA 17 & $19 \pm 1.0$ & $18 \pm 1.0$ & $15 \pm 1.0$ & $15 \pm 1.0$ & $13 \pm 1.0$ & $37 \pm 1.0$ \\
\hline SA 18 & $20 \pm 1.0$ & $18 \pm 1.0$ & $17 \pm 1.0$ & $17 \pm 1.0$ & $15 \pm 1.0$ & $30 \pm 1.0$ \\
\hline SA 19 ATCC 6538 & $20 \pm 1.0$ & $18 \pm 1.0$ & $16 \pm 1.0$ & $14 \pm 1.0$ & $14 \pm 1.0$ & $25 \pm 1.0$ \\
\hline SA 20 NCT 6571 & $21 \pm 1.0$ & $19 \pm 1.0$ & $18 \pm 1.0$ & $16 \pm 1.0$ & $13 \pm 1.0$ & $30 \pm 1.0$ \\
\hline
\end{tabular}

Key: $\mathrm{SA}=$ Different strains of $S$. aureus.

The antibacterial activity of the ethanol extract may be attributed to the presence of many pharmacologically bioactive compounds such as alkaloids, flavonoids, tannins, anthraquinones and phenolic compounds which have been previously associated with the antibacterial activity of many plants (EDEOGA et al., 2005; NAWROT et al., 2007). To have attained such degree of antibacterial activity, the extract may have possessed certain membrane active compounds capable of disrupting the function and permeability of biological membranes (ABEL et al., 2002; RAMACHANDRAN et al., 2004). While the extent of adsorption onto the membranes due to surface activity has been correlated with the damaging effects likely to be produced (ATTWOOD and FLORENCE, 1983), the degree of the susceptibility of strains of $S$. aureus, used in this study, is not surprising. Being Gram positive cocci, the 
cytoplasmic membrane with plenty of pores allowed inflow of foreign molecules without any difficulty (LIN et al., 2003; GoUDA, 2008). Although, with the exception of SA15 that had MIC of $0.019 \mathrm{mg} / \mathrm{ml}$, all the isolates resistant to nitrofurantoin had MICs equal to $5.0 \mathrm{mg} / \mathrm{ml}$ of the extract. The difference in the susceptibility of these isolates to the extract and antibiotic used as control may be due to the incomparable differences in the crudeness of the extract and the degree of purity of the nitrofurantoin as well as stearic hindrance preventing the extract from diffusing easily through the agar gel.

Table 3: Minimum inhibitory and minimum bactericidal concentrations of ethanol extract of Tetrapleura tetraptera against different strains of Staphylococcus aureus.

\begin{tabular}{|c|c|c|}
\hline \multirow{3}{*}{$\begin{array}{c}\text { ORGANISMS } \\
\text { Test } \text { Staphylococcus } \text { strains }\end{array}$} & \multicolumn{2}{|c|}{ Ethanol extract } \\
\hline & MIC & MBC \\
\hline & \multicolumn{2}{|c|}{$\mathrm{mg} / \mathrm{ml}$} \\
\hline SA 1 & 0.3125 & 1.25 \\
\hline SA 2 & 2.5 & 5.0 \\
\hline SA 3 & 0.039 & 0.078 \\
\hline SA 4 & 5.0 & 10.0 \\
\hline SA 5 & 0.019 & 0.078 \\
\hline SA 6 & 5.0 & 10.0 \\
\hline SA 7 & 2.5 & 5.0 \\
\hline SA 8 & 5.0 & 5.0 \\
\hline SA 9 & 5.0 & 5.0 \\
\hline SA 10 & 2.5 & 2.5 \\
\hline SA 11 & 0.019 & 0.078 \\
\hline SA 12 & 1.25 & 5.0 \\
\hline SA 13 & 0.019 & 0.039 \\
\hline SA 14 & 0.019 & 0.156 \\
\hline SA 15 & 0.019 & 0.039 \\
\hline SA 16 & 0.3125 & 0.625 \\
\hline SA 17 & 0.019 & 0.156 \\
\hline SA 18 & 0.019 & 0.078 \\
\hline SA 19 ATCC 6538 & 5.0 & 5.0 \\
\hline SA 20 NCT 6571 & 5.0 & 5.0 \\
\hline
\end{tabular}

Key: SA = Different strains of $S$. aureus

\section{CONCLUSION}

In conclusion, the degree of antibacterial activity exhibited by the extract of Tetrapleura tetraptera demonstrated that its herbal medicine could be as effective as modern medicine in treating diseases associated with the test pathogenic organism and justifying its traditional use in the treatment of bacterial infections. Since all herbal medicines and botanical drugs will have to fulfil the international requirements on quality, safety and efficacy, further study, which is ongoing in our laboratory, should be carried out on its toxicity in order to know its safety and toxicity profile and establish a safe dosage regimen since the concoction is taken orally by local people for treating gastrointestinal infections as well as isolate and purify novel, effective and inexpensive drugs of great importance. 


\section{References:}

[1] Abel, T., Cohen, J.I., Engel, R., Filshtinskaya, M., Melkonian, A., Melkonian, K. (2002): Preparation and investigation of antibacterial carbohydrate-based surfaces. Carbohydrate Res. 337: 2495-2499. doi: 10.1016/S0008-6215(02)00316-6

[2] ACHI, O.K. (2006): Composition and antibacterial activities of Tetrapleura tetraptera Taub pod extracts. Research Journal of Microbiology 1 (5): 416-422. doi: 10.3923/jm.2006.416.422

[3] Adesina, S.K., IwalewA, E.O., Jonny, I.I. (2016): Tetrapleura tetraptera Taub Ethnopharmacology, Chemistry, Medicinal and Nutritional Values - A Review. British Journal of Pharmaceutical Research 12 (3): 1-22. doi: 10.9734/BJPR/2016/26554

[4] Aderibigbe, A.O., Iwalewa, E.O., Adesina, S.K., Ukponmwan, O.E., Adebanjo, A.O. (2007): Neuropharmacological evaluation of Aridanin, A glycoside isolated from Tetrapleura tetraptera Fruit. Discovery and Innovation 19 (3): 177-181. doi: 0.4314/dai.v19i3.15799

[5] Akin-Idowu, P.E., Ibitoye, D.C., Ademogegun, O.T., Adenyi, O.T. (2011): Chemical Composition of the dry fruit of Tetrapleura tetraptera and its potential impacts on human health. Journal of Herbs, Spices and Medicinal Plants 17: 52-61. doi: $10.1080 / 10496475.2011 .560087$

[6] Akintola O.O., Bodede, A.I., Ogunbanjo, O.R. (2015): Nutritional and medicinal importance of Tetrapleura tetraptera fruits (Aridan). African Journal of Science and Research 4 (6): 33-38.

[7] Aladesanmi, A.J. (2007): Tetrapleura tetraptera: Molluscicidal activity and chemical constituents. African Journal of Traditional, Complementary and Alternative Medicine 4 (1): 23-36. doi: 10.4314/ajtcam.v4i1.31189

[8] Anselem, A. (2004): Nature Power. Christian approach to herbal medicine, $3^{\text {rd }}$ ed. Publ. Generation Press Ltd., Lagos, Nigeria, pp. 290.

[9] AQIL, F., Khan, M.S., OwAIS, M., AhMAD, I. (2005): Effect of certain bioactive plant extracts on clinical isolates of beta-lactamase producing methicillin-resistant Staphylococcus aureus. Journal of Basic Microbiology 45: 106-114. doi: 10.1002/jobm.200410355

[10] Arias, M.E., Gomez, J.D., Cudmani, N., Vattuone, M.A., Isla, M.I. (2004): Antibacterial activity of ethanolic and aqueous extract of Acacia aroma Gill ex Hook et. Life Sciences 75 (2): 191-202. doi: 10.1016/j.lfs.2003.12.007

[11] Attwood, D., Florence, A.T. (1983): Surfactant systems: Their chemistry, pharmacy and biology. Chapman and Hall Ltd., London, p. 124-228, 388-468, 607-610.

[12] Awofisayo, S.O., Udoh, I.E., Mbagwu, H.O.C. (2010): Antibacterial effects of the aqueous and ethanolic effects of Tetrapleura tetraptera pods on the pathogens in nosocomial wound infections. IJPI Journal of Pharmacognosy and Herbal Formulations 1 (2): 18-23 
[13] Ayoka, A.O., Akomolafe, R.O., Akinsomisoye, O.S., Ukpomwan, O.E. (2008): Medicinal and economic value of Spondia mombin. African Journal of Biomedical Research 11 (2): 129-136. doi: 10.4314/ajbr.v11i2.50714

[14] Badu, M., Mensah, J.K., BoAdi, N.O. (2012): Antioxidant activity of methanol and ethanol/water extracts of Tetrapleura tetraptera and Parkia biglobosa. International Journal of Pharmacy and Biological Sciences 3 (3): 312-321.

[15] Block, J.E., Stubbs, H.A. (2005). Reducing the risk of deep wound infection in primary joint arthroplasty with antibiotic bone cement. Orthopedics 28 (11): 1334-1345.

[16] BouQueT, A.A.P. (1972): Plantes medicinales du Congo-Brazzaville. Plantes Medicinales et Phytotherapie, Tome 5, No. 2: 154-158.

[17] Cheesbrough, M. (2002): Medical Laboratory Manual for Tropical Countries. ELBS ed; Tropical Health Technology publications and Butterworth-Heinemann Ltd: Cambridge, UK 2: 2-392.

[18] Cheesbrough, M. (2009): District Laboratory Practice in Tropical Countries, Part 2: Cambridge University press, Cambridge: 62-69.

[19] Choi, J.G., Kang, O.H., Obiang-Obounou, B., LeE, Y.S., ChaE, H.S., OH, Y.C., Sohn, D.H., PArK, H,. ChOI, H.G., KIM, S.G., ShIN, D.W., Kwon, D.Y. (2010): Antibacterial activity of Ecklonia cava against methicillin-resistant Staphylococcus aureus and Salmonella spp. Foodborne Pathogen and Disease 7: 435-441. doi: 10.1089/fpd.2009.0434

[20] Clinical And Laboratory Standards Institute (CLSI) (2013): Performance Standards for Antimicrobial Susceptibility Testing; Twenty third Informational Supplement. CLSI document M100-S23. Wayne, PA, USA.

[21] Clinical And Laboratory Standards Institute (CLSI) (2007): Performance Standards for Antimicrobial Susceptibility Testing; Seventeenth Informational Supplement. CLSI document M100-S17. Wayne, PA, USA.

[22] DARouiche, R.O. (2003): Antimicrobial approaches for preventing infections associated with surgical implants. Clinical Infectious Diseases 36 (10): 1284-1289. doi: $10.1086 / 374842$

[23] Edeoga, H.O., Okwu, D.E., Mbaebie, B.O. (2005): Phytochemical constituents of some Nigerian medicinal plants. African Journal of Biotechnology 4 (7): 685-688. doi: 10.5897/AJB2005.000-3127

[24] ElOFF, J.N. (2008): Quantification the bioactivity of plant extracts during screening and bioassay guided fractionation. Phytomedicine 11 (4): 370-371. doi: $10.1078 / 0944711041495218$

[25] EUROPEAN COMMITTEE For ANTIMICROBIAL SusCEPTIBILITY TESTING (EUCAST) (2000): Determination of minimum inhibitory concentrations (MICs) of antibacterial agents by agar dilution. Clinical Microbiology and Infection 6: 509-515. doi: 10.1046/j.1469-0691.2000.00142.x

[26] Faria, N.A., Oliveira, D.C., Westh, H., Monnet D.L., Larsen A.R., Scov, R., DE LENCASTRE, H. (2005): Epidemiology of emerging methicillin-resistant Staphylococcus aureus (MRSA) in Denmark: a nationwide study in a country with low prevalence of 
MRSA infection. Journal of Clinical Microbiology 43 (4): 1836-1842. doi: 10.1128/JCM.43.4.1836-1842.2005

[27] Fasching, C.E., Peterson, L.R., Moody, J.A., Sinn, L.M., Gerding, D.N. (1990): Treatment evaluation of experimental staphylococcal infections comparing $\beta$-lactam, lipopeptide, and glycopeptide antimicrobial therapy. Journal of Laboratory and Clinical Medicine 116: 697-706.

[28] Forbes, B.A., SAhM, D.F., Weissfeld, A.S. (2007): Bailey and Scott's diagnostic microbiology, $12^{\text {th }}$ ed. Mosby; p. 98-257.

[29] GoudA, M. (2006): Enhancing flame-resistance and antibacterial properties of cotton fabric. Journal of Industrial Textiles 36 (2): 167-177. doi: 10.1177/1528083706068677

[30] Holt, J.G., KRIEG, N.R., Sneath, P.H.A., Williams, S.T. (1994): Staphylococcus spp. In: Bergey's manual of determinative bacteriology, $9^{\text {th }}$ ed. Baltimore, MD: Williams \& Wilkiins; p. 544-51.

[31] Huang, R., Mehtal, S., Weed, D., Price, C.S. (2006): Methicillin-resistant Staphylococcus aureus survival on hospital fomites. Infection Control and Hospital Epidemiology 27 (11): 1267-1269. doi: 10.1086/507965

[32] Irondi, A.E., Anokam, K.K., Chukwuma, P.C., Akintunde, J.K., Nurain, I.O. (2013): Variation in nutrients composition of Tetrapleura tetraptera fruit at tow maturity stages. International Journal of Biosciences 3 (9): 304-312. doi: 10.12692/ijb/3.9.304-312

[33] Khan, A., Rhaman, M., Islam, S. (2007): Antibacterial, antifungal and cytotoxic activities of tuberous roots of Amorphophallus campanulatus. Turkish Journal of Biology 31: 167-172.

[34] Kuete, V. (2010): Potential of Cameroonian plants and derived products against microbial infections: a review. Planta Medica 76 (14): 1479-1491. doi: 10.1055/s-00301250027

[35] Lekana-Douki, J.B., Liabagui, S.L.O., Bongui, J.B., Zatra, R., Lebibi, J., TourNDOUO, F.S. (2011): In vitro antiplasmodial activity of crude extracts of Tetrapleura tetraptera and Copaifera religiosa. BMC Research Notes 4: 506. doi: 10.1186/17560500-4-506

[36] Lin, J., QIU, S., Lewis, K., KLIBAnOV, A.M. (2003): Mechanism of bactericidal and fungicidal activities of textiles covalently modified with alkylated polyethylenimine. Biotechnology and Bioengineering 83 (2): 168-172. doi: 10.1002/bit.10651

[37] Maillard, M., Adewunmi, C.O., Hostettman, K. (1992): A triterpene glycoside from the fruit of Tetrapleura tetraptera. Phytochemistry 31 (4): 1321-1323. doi: 10.1016/0031-9422(92)80500-E

[38] Makanjuola, O.Y., Dada, O.E., AkharaiYi, F.C. (2010): Antibacterial potentials of Parquetina nigrescens extracts on some selected pathogenic bacteria. Journal of Natural Products 3: 124-129.

[39] Marchese, A., Shito, G.C. (2000): Resistance patterns of lower respiratory tract pathogens in Europe. International Journal of Antimicrobial Agents 16 (Supplement 1): 25-29. doi: 10.1016/S0924-8579(00)00302-2 
[40] Millar, B.C., Loughrey, A., Elborn, J.S., Moore, J.E. (2007): Proposed definitions of community-associated meticillin-resistant Staphylococcus aureus (CA-MRSA). Journal of Hospital Infections 67 (2): 109-13. doi: 10.1016/j.jhin.2007.06.003

[41] Moody, J.A., Fasching, C.E., Peterson, L.R., Gerding, D.N. (1987): Ceftazidime and amikacin alone and in combination against Pseudomonas aeruginosa and Enterobacteriaceae. Diagnostic Microbiology and Infectious Disease 6 (1): 59-67. doi: 10.1016/0732-8893(87)90115-5

[42] Muder, R.R., Brennen, C., Rihs, J.D., Wagener, M.M., ObMan, A., Stout, J.E., Yu, V.L. (2006): Isolation of Staphylococcus aureus from the urinary tract: Association of symptomatic tract infection and subsequent staphylococcal bacteremia. Clinical Infectious Diseases 42 (1): 46-50. doi: 10.1086/498518

[43] Nawrot, R., Lesniewicz, K., Pienkowska, J., Gozdzicka-Jozefiak, A. (2007): A novel extracellular peroxidase and nucleases from a milky sap of Chelidonium majus. Fitotherapia 78 (7-8): 496-501. doi: 10.1016/j.fitote.2007.04.012

[44] Nijssen, S., Bonten, M.J., Weinstein, R.A. (2005): Are active microbiological surveillance and subsequent isolation needed to prevent the spread of methicillin resistant Staphylococcus aureus? Clinical Infectious Diseases 40 (3): 405-409. doi: $10.1086 / 427281$

[45] Nuume, C., Afolayan, A.J., NDIP, R.N. (2011): Preliminary phytochemical screening and in vitro anti-Helicobacter pylori activity of acetone and aqueous extracts of the stem bark of Sclerocarya birrea (Anacardiaceae). Archives of Medical Research 42 (3): 252257. doi: 10.1016/j.arcmed.2011.04.009

[46] NwaiwU, J.I., AKAH, P.A. (1986): Anticonvulsant activity of the volatile oil from the fruit of Tetrapleura tetraptera. Journal of Ethnopharmacology 18 (2): 103-107. doi: 10.1016/0378-8741(86)90023-1

[47] NyENJE, M., NDIP, R.N. (2011): In vitro antimicrobial activity of crude acetone extract of the stem bark of Combretum molle against selected bacterial pathogens. Journal of Medicinal Plants Research 5 (21): 5315-5320.

[48] OJEwole, J.A.O., AdESINA, S.K. (1983): Cardiovascular and neuromuscular actions of scopoleptin from fruit of Tetrpleura tetraptera. Planta Medica 48: 99-102. doi: $10.1055 / \mathrm{s}-2007-969824$

[49] OJEwOle, J.A., AdEwUnMI, C.O. (2004): Anti-inflammatory and hypoglycaemic effects of Tetrapleura tetraptera (Taub) [Fabaceae] fruit aqueous extract in rats. Journal of Ethnopharmacology 95 (2-3): 177-182. doi: 10.1016/j.jep.2004.06.026

[50] OJEwole, J.A. (2005): Analgesic and anticonvulsant properties of Tetrapleura tetraptera (Taub) (Fabaceae) fruit aqueous extract in mice. Phytotherapy Research 19 (12): 1023-1029. doi: 10.1002/ptr.1779

[51] OKwU, D.E. (2003): The potentials of Ocimum gratissimum, Pengularia extensa and Tetrapleura tetraptera as spice and flavouring agent. Nigeria Agricultural Journal 34: 143-148. doi: 10.4314/naj.v34i1.3184

[52] Olajuyigbe, O.O., Afolayan, A.J. (2012): In vitro pharmacological activity of the crude acetone extract of Erythrina caffra Thunb: antibacterial and antifungal 
assessment. Journal of Medicinal Plants Research 6 (9): 1713-1720. doi: 10.5897/JMPR11.1517

[53] Onda, E.E., Sonibare, M.A., Ajayi, A.M., Umukoro, S. (2017): Anti-inflammatory and antioxidant effects of Tetrapleura tetraptera (Schumach \& Thonn.) Taub. fruit extract in Carrageenan/Kaolin-induced acute monoarthritis in rats. Nigerian Journal of Pharmaceutical Research 13 (2): 157-166.

[54] Pastila, S., Sammalkorpi, K.T., Vuopio-Varkila, J., Kontiainen, S., Ristola, MA. (2004): Control of methicillin-resistant Staphylococcus aureus outbreak involving several hospitals. Journal of Hospital Infection 58 (3): 180-186. doi: 10.1016/j.jhin.2004.06.024

[55] Prusti, A., Mishra, S.R., Sahoo, S., Mishra, S.K. (2008): Antibacterial activity of some Indian medicinal plants. Ethnobotanical Leaflets 2008 (1): 227-230.

[56] Ramachandran, T., Rajendrakumar, K., RAJEndRan, R. (2004): Antimicrobial textiles - An Overview. Int. Expl, (India) Journal-Textile 84 (2): 42-47.

[57] Rotter, ML. (1999): Handwashing and hand disinfection. In: Mayhall C.G. (ed) Hospital epidemiology and infection contro, $2^{\text {nd }}$ ed. Lippincott Williams \& Wilkins, Philadelphia, Pa: 1339-1355.

[58] Shanholtzer, C.J., Peterson, L.R., Mohn, M.L., Moody, J.A., Gerding, D.N. (1984): MBCs for Staphylococcus aureus as determined by macrodilution and microdilution techniques. Antimicrobial Agents Chemotherapy 26 (2): 214-219. doi: 10.1128/AAC.26.2.214

[59] Soberon, J.R., Sgariglia, M.A., Sampietro, D.A., Quiroga, E.N., Vattuone, M.A. (2007): Antibacterial activity of plant extracts from Northwest Argentina. Journal of Applied Microbiology 102 (6): 1450-1461. doi: 10.1111/j.1365-2672.2006.03229.x

[60] Steentoft, M. (1988): Flowering plants in West Africa. Cambridge University Press. ISBN 0-521-26192-9. pp: 1-364.

[61] Suffredini, J.B., Sader, H.S., Goncalves, A.G., Reis, A.O., Gales, A.C., Varella, A.D., Younes, R.N. (2004): Screening of antimicrobial extracts from plants native to the Brazilian Amazon rainforest and Atlantic forest. Brazil Journal of Medical and Biological Research 37 (3): 379-384. doi: 10.1590/S0100-879X2004000300015

[62] Voss, A. (2004): Preventing the spread of MRSA. British Medical Journal 329 (7465): 521. doi: $10.1136 / \mathrm{bmj} .329 .7465 .521$

[63] Wertheim, H.F., Melles, D.C., Vos, M.C., Van Leeuwen, W., Van Belkum, A., Verbrugh, H.A., Nouwen, J.L. (2005): The role of nasal carriage in Staphylococcus aureus infections. Lancet Infectious Diseases 5 (12): 751-762. doi: 10.1016/S14733099(05)70295-4 